\title{
Harga, Lokasi dan Kualitas Pelayanan Penentu Minat Beli Konsumen
}

\author{
Halimatus Sadiyah \\ Universitas Wijaya Putra Surabaya \\ halimatussadiyah290@gmail.com
}

\begin{abstract}
The purpose of this study was to describe and determine the effect of price, location and service quality on consumer buying interest in the BUMDesa Pengalangan Menganti Gresik business market. The sample used was 60 respondents with a questionnaire data instrument. The analysis used is multiple linear regression analysis. The results showed that the price partially had no effect on consumer buying interest in the BUMDesa Penganti Gresik Business Market, the location partially had a significant positive effect on consumer buying interest in the BUMDesa Pengalangan Business Market and the service quality partially had a significant positive effect on consumer buying interest. at the BUMDesa Penganti Gresik Business Market. Simultaneously, price, location and service quality have a significant positive effect on consumer buying interest in the Penganti Gresik BUMDesa Business Market.
\end{abstract}

Keywords: Price, Location, Quality of Service and Consumer Purchase Interest.

\begin{abstract}
Abstrak: Tujuan penelitian ini adalah untuk mendeskripsikan dan mengetahui pengaruh harga, lokasi dan kualitas pelayanan terhadap minat beli konsumen pada pasar usaha BUMDesa Pengalangan Menganti Gresik. Sampel yang digunakan adalah sebanyak 60 responden dengan instrumen data kuesioner. Analisis yang digunakan adalah analisis regresi linier berganda. Hasil penelitian menunjukkan bahwa harga secara parsial tidak berpengaruh terhadap minat beli konsumen pada Pasar Usaha BUMDesa Pengalangan Menganti Gresik, lokasi secara parsial berpengaruh positif signifikan terhadap minat beli konsumen pada Pasar Usaha BUMDesa Pengalangan Menganti Gresik dan kualitas pelayanan secara parsial berpengaruh positif signifikan terhadap minat beli konsumen pada Pasar Usaha BUMDesa Pengalangan Menganti Gresik. Secara simultan harga, lokasi dan kualitas pelayanan berpengaruh positif signifikan terhadap minat beli konsumen pada Pasar Usaha BUMDesa Pengalangan Menganti Gresik.
\end{abstract}

Kata Kunci: Harga, Lokasi, Kualitas Pelayanan dan Minat Beli Konsumen. 


\section{PENDAHULUAN}

Keterbatasan manusia dalam memenuhi kebutuhannya yang sudah berlangsung sejak manusia itu ada sehingga muncul sistem perdagangan sebagai solusi. Manusia memiliki beberapa kebutuhan dalam memenuhi kelangsungan hidup diantaranya memerlukan adanya pasar sebagai sarana pendukungnya dalam kehidupan sehari-hari. Pasar sudah menjadi suatu komponen penting dalam kehidupan terutama untuk fasilitas umum yang digunakan sebagai tempat transaksi jual beli secara langsung dan tidak langsung dengan pedagang, pembeli, serta barang yang dijual dan tentunya pasar begitu akrab dengan lingkungan masyarakat, baik dikota maupun didesa. Menurut Umar (2003), Pasar adalah sebuah mekanisme yang dapat mempertemukan pihak penjual dan pembeli untuk melakukan transaksi atas barang dan jasa, serta proses penentuan harga. Syarat utama terbentuknya pasar adalah bertemunya penjual dan pembeli, baik dalam satu tempat ataupun dalam tempat yang berbeda. Pasar dikategorikan dalam dua jenis yaitu pasar tradisional dan pasar modern.

Pasar Tradisional menjadi salah satu jantung perekonomian masyarakat di Indonesia. Kedudukan masyarakat sangat penting dan menyatu dalam kehidupan masyarakat. Pasar Tradisional dapat disebut sebagai kearifan lokal, dimana menurut Digdoyo (2015:104) kearifan lokal lebih mengarah pada seperangkat pengetahuan yang dimiliki masyarakat yang tinggal di suatu wilayah, didukung oleh teknologi yang diciptakan untuk menopang kehidupan sehari-hari. Pasar tradisional sebagai bagian dari budaya masyarakat lokal harus dilestarikan keberadaannya agar kelak tak menjadi cerita yang hanya diterka.

Namun dalam perkembangannya, keberadaan pasar tradisional mulai terancam dengan munculnya berbagai bentuk pasar modern dengan cara pasar modern muncul menawarkan konsep baru kepada masayarakat. Melihat persaingan yang semakin ketat bisnis ritel harus mampu meningkatkan berbagai varian produk dalam jumlah yang lebih banyak dari sebelumnya, keinginan konsumen dengan produk yang lebih banyak di tawarkan tersebut mampu memuaskan konsumen untuk melakukan minat beli masyarakat.

Harga merupakan bagian penentu yang ada dalam suatu penjualan, dan setiap produk yang dijual pasti memiliki harga yang dicantumkan, konsumen lebih peka terhadap harga. Perbedaan harga sedikit saja pada tingkat harga dapat menimbulkan pergeseran minat beli.

Lokasi menjadi salah satu faktor yang mempengaruhi keputusan pembelian. Konsumen cenderung memilih lokasi yang mudah dijangkau dibandingkan dengan lokasi yang sulit untuk menjangkaunya karena jauh. Ketatnya persaingan diantara pesaing menjadikan lokasi sebagai faktor penting dalam kesuksesan bisnis karena sebelum 
memutuskan untuk berkunjung, konsumen tentu mempertimbangkan juga lokasi dari tempat tinggal tersebut.

Faktor utama yang mempengaruhi kualitas pelayanan adalah pelayanan yang diharapkan pelanggan dan persepsi masyarakat terhadap pelayanan tersebut. Karena dalam proses minat membeli terdapat evaluasi dan pengambilan keputusan sebelum melakukan pembelian, Ketika kualitas pelayanan yang diberikan kurang baik akan berakibat menurunnya minat beli konsumen karena mereka merasakan ketidakpuasan sehingga konsumen akan berpaling ke tempat yang lain.

\section{TINJAUAN TEORITIS}

\section{Minat Beli}

Minat beli adalah tahap dimana konsumen atau pembeli telah menentukan pilihannya dan melakukan pembelian produk serta mengkonsumsinya (Ali dan Novansa, 2017). Pengambilan keputusan oleh konsumen untuk melakukan pembelian suatu produk diawali oleh adanya kesadaran atas kebutuhan dan keinginan (Ali dan Novansa, 2017). Menurut (Adiba, 2016) Minat beli merupakan bagian dari komponen perilaku dalam sikap mengkonsumsi. Sedangkan menurut Utami dan Saputra (2017) minat beli merupakan hasil evaluasi dari dalam diri individu seorang konsumen tentang suatu produk atau jasa, mengenai kualitas, kemampuan serta keuntungan apa saja yang akan diperoleh jika mengkonsumsi produk tersebut.

\section{Harga}

Harga merupakan sejumlah uang yang dikeluarkan oleh konsumen untuk sebuah produk dan jasa atau sejumlah nilai yang ditukarkan oleh konsumen untuk memperoleh manfaat atau kepemilikan atau penggunaan atas sebuah produk atau jasa Kotler dan Keller (2016). Harga merupakan satu-satunya unsur bauran pemasaran yang memberikan pendapatan bagi organisasi. Secara sederhana harga dapat diartikan sebagai jumlah (satuan moneter) atau aspek lain (non moneter) yang mengandung utilitas atau kegunaan tertentu untuk mendapatkan suatu produk (Satria, 2017).

\section{Lokasi}

Menurut Lupiyoadi (2001) lokasi adalah tempat dimana suatu usaha atau aktivitas usaha dilakukan Faktor penting dalam pengembangan suatu usaha adalah letak lokasi terhadap daerah perkotaan, cara pencapaian dan waktu tempuh lokasi ke tujuan. Menurut Utami (2017) lokasi ritel adalah sebuah keputusan yang sangat strategis. Sekali lokasi dipilih, pemilik ritel harus menanggung semua konsekuensi dari pilihan tersebut. 
Sedangkan lokasi menurut Lupiyoadi (2001) merupakan keputusan yang dibuat perusahaan dimana perusahaan harus bertempat dan beroperasi.

\section{Kualitas Pelayanan}

Menurut Kotler dan Keller (2016) kualitas pelayanan merupakan totalitas dari bentuk karakteristik barang dan jasa yang menunjukkan bahwa kemampuannya untuk memuaskan kebutuhan pelanggan baik yang nampak jelas maupun yang tersembunyi. Sedangkan menurut Tjiptono (2016: 87) Kualitas pelayanan adalah upaya pemenuhan kebutuhan yang dibarengi dengan keinginan konsumen dan ketepatan cara penyampaiannya agar dapat memenuhi harapan erta kepuasan pelanggan tersebut

\section{Kerangka Konseptual}

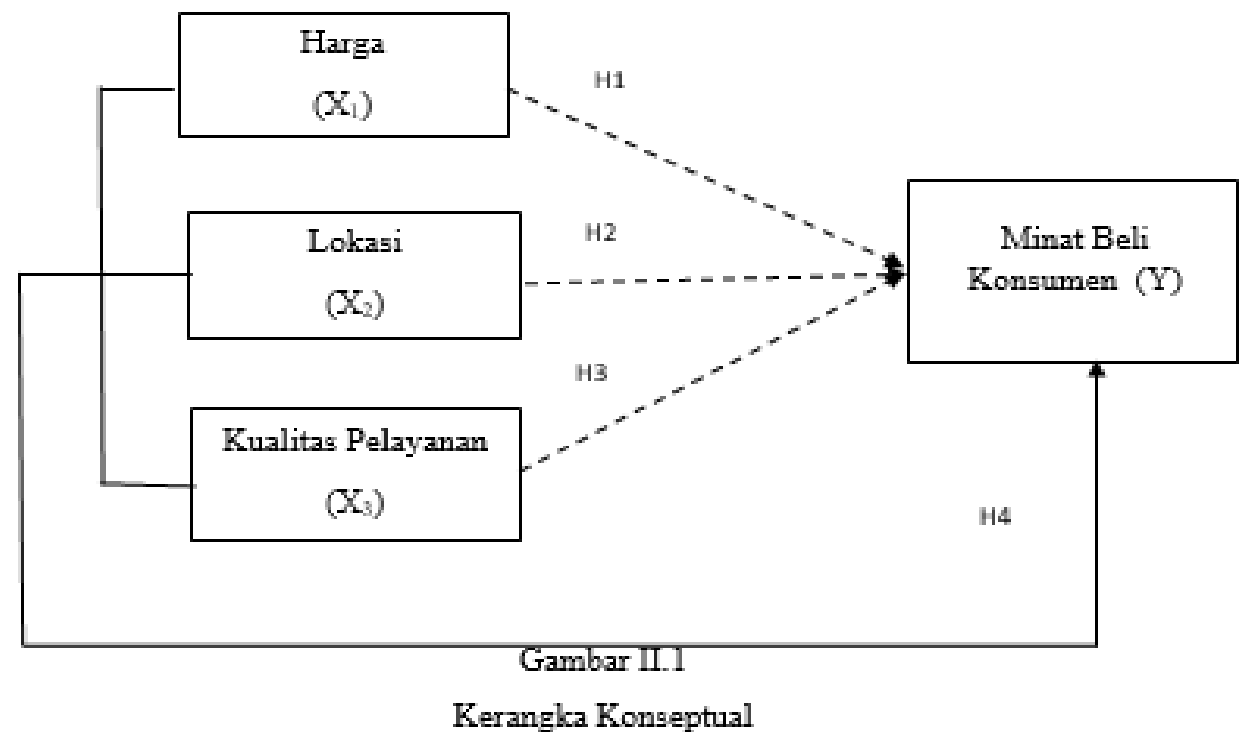

\section{METODOLOGI PENELITIAN}

\section{Jenis dan Pendekatan Penelitian}

Jenis penelitian ini adalah penelitian survei. Penelitian survei adalah penelitian yang dilakukan pada populasi besar maupun kecil, tetapi data yang dipelajari adalah data dari sampel yang di ambil dari populasi tersebut, sehingga ditemukan kejadian-kejadian relative, distribusi, dan hubungan - hubungan antar variabel sosiologis maupun psikologis (Sugiyono, 2019). Pendekatan penelitian yang digunakan dalam penelitian ini adalah kuantitatif. Metode kuantitatif dapat diartikan sebagai metode penelitian yang berlandasakan pada filsafat positivisme, digunakan untuk meneliti pada populasi atau sampel tertentu, pengumpulan data menggunakan instrumen penelitian, analisis data bersifat kuantitatif/statistik, dengan tujuan untuk menguji hipotesis yang ditetapkan 
(Arikunto, 2010). Penelitian ini berdasarkan tingkat eksplanasinya, bersifat asosiatif kausal yang bertujuan untuk mengetahui pengaruh dua variabel bebas atau lebih terhadap variabel terikat, dimana penelitian ini mencari pengaruh variabel bebas yaitu mengenai harga (X1), lokasi (X2), dan kualitas pelayanan (X3) terhadap variabel terikat minat beli konsumen di Pasar Usaha BUMDesa Pengalangan Menganti Gresik (Y). Alat analisis yang digunakan dalam penelitian ini menggunakan analisis regresi linier berganda.

\section{Lokasi Penelitian}

Lokasi penelitian merupakan tempat dimana peneliti melakukan penelitian untuk memperoleh data-data yang diperlukan. Penelitian ini dilaksanakan di Pasar Usaha BUMDesa Pengalangan beralamatkan di Jl. Dusun Dukuh Kelurahan Pengalangan Kec. Menganti Kabupaten Gresik.

\section{Populasi, Sampel dan Teknik Pengambilan Sampel}

Populasi dalam penelitian ini adalah seluruh konsumen yang berbelanja di pasar usaha BUMDesa Pengalangan Menganti Gresik. Menurut Sugiyono (2019) Sampel merupakan " bagian dari jumlah dan karakteristik yang dimiliki oleh populasi tersebut. Sampel diambil sebanyak 60 responden dengan cara menggunakan probability sampling dengan jenis simple Rondom Sampling. Menurut Sugiyono (2019) bahwa: "dikatakan simple (sederhana) karena pengambilan sampel dari populasi dilakukan secara acak tanpa memperhatikan strata yang ada dalam populasi itu. Teknik pengumpulan data menggunakan kuesioner, dengan metode analisa data yang digunakan analisis regresi linier berganda menggunakan program SPSS versi 21.

\section{HASIL DAN PEMBAHASAN}

\section{Deskripsi Hasil Penelitian}

Hasil analisis deskripsi untuk karakteristik responden yang meliputi jenis kelamin, usia, pekerjaan, dan intensitas kunjungan responden pada Pasar Usaha BUMDesa Pengalangan Menganti Gresik. Diketahui bahwa Mayoritas Responden adalah Perempuan yaitu sebanyak 45 orang (75,0 \%), usia mayoritas 17-25 tahun sebanyak 20 orang $(33,3 \%)$, pekerjaan mayoritas adalah karyawan swasta dan lain-lain sebanyak 18 orang $(30,0 \%)$, dan yang terakhir frekuensi kunjungan sebanyak >20 kali $(36,7 \%)$. 


\section{Hasil Analisis Regresi Linier Berganda}

\section{Analisis Regresi Linier Berganda}

\section{Coefficients $^{\mathrm{a}}$}

\begin{tabular}{|c|c|c|c|c|c|c|}
\hline \multirow{2}{*}{\multicolumn{2}{|c|}{ Model }} & \multicolumn{2}{|c|}{ Unstandardized Coefficients } & \multirow{2}{*}{$\begin{array}{l}\text { Standardized } \\
\text { Coefficients } \\
\text { Beta }\end{array}$} & \multirow[t]{2}{*}{$\mathrm{t}$} & \multirow[t]{2}{*}{ Sig. } \\
\hline & & B & Std. Error & & & \\
\hline \multirow{4}{*}{1} & (Constant) & ,443 & 1,835 & & ,241 &, 810 \\
\hline & $\mathrm{X} 1$ & ,318 &, 160 & ,234 & 1,991 &, 051 \\
\hline & $\mathrm{X} 2$ & ,346 & 159 & ,235 & 2,178 &, 034 \\
\hline & $\mathrm{X} 3$ & ,342 & ,104 & ,391 & 3,291 &, 002 \\
\hline
\end{tabular}

a. Dependent Variable: Y

Maka diperoleh hasil-hasil pengujian sebagai mana terlihat bisa dihasilkan formula regresi linier berganda sebagai berikut:

$Y=\beta_{0}+\beta_{1} X_{1}+\beta_{2} X_{2}+\beta_{3} X_{3}$

$Y=0,443+0,318 X_{1}+0,346 X_{2}+0,342 X_{3}$

Pada persamaan regresi linier berganda di atas menunjukkan bahwa:

1. Pengaruh Harga $\left(\mathrm{X}_{1}\right)$ terhadap minat beli konsumen $(\mathrm{Y})$ adalah positif sebesar 0,318 . Data ini menunjukkan bahwa harga $\left(\mathrm{X}_{1}\right)$ mengalami kenaikan sejumlah 0,318 satuan maka minat beli konsumen (Y) akan mengalami kenaikan sejumlah 0,318. Begitu pula sebaliknya, dengan asumsi variabel lokasi $\left(\mathrm{X}_{2}\right)$ dan kualitas pelayanan $\left(\mathrm{X}_{3}\right)$ bernilai tetap atau nol (0).

2. Pengaruh Lokasi (X2) terhadap minat beli konsumen (Y) adalah positif sebesar 0,346. Data ini menujukkan bahwa jika lokasi $\left(\mathrm{X}_{2}\right)$ mengalami kenaikan sejumlah 0,346 satuan maka minat beli konsumen (Y) juga akan mengalami kenaikan sejumlah 0,346. Begitu pula sebaliknya, dengan asumsi variabel harga $\left(\mathrm{X}_{1}\right)$ dan kualitas pelayanan $\left(\mathrm{X}_{3}\right)$ bernilai tetap atau nol $(0)$.

3. Pengaruh Kualitas Pelayanan (X3) terhadap minat beli (Y) adalah positif sebesar 0,342. Data ini menunjukkan bahwa jika kualitas pelayanan (X3) mengalami kenaikan sejumlah 0,346 satuan maka minat beli konsumen (Y) juga mengalami kenaikn sejumlah 0,346. Begitu pula sebaliknya, dengan asumsi variabel harga (X1) dan lokasi (X2) bernilai tetap atau nol (0).

4. Selanjutnya, model persamaan regresi linier berganda di atas juga menunjukkan bahwa nilai konstanta yang dihasilkan adalah bernilai positif sebesar 0.443 , yang artinya bahwa jika tidak ada pengaruh dari variabel bebas harga $\left(\mathrm{X}_{1}\right)$, lokasi $\left(\mathrm{X}_{2}\right)$, kualitas pelayanan $\left(\mathrm{X}_{3}\right)$, maka variabel terikat yang merupakan minat beli konsumen (Y) adalah berniali positif sebesar 0.443 . 


\section{Hasil Koefisien Determinasi Berganda}

Model Summary ${ }^{\mathrm{b}}$

\begin{tabular}{|c|c|c|c|c|c|}
\hline Model & $\mathrm{R}$ & $\mathrm{R}$ Square & $\begin{array}{c}\text { Adjusted R } \\
\text { Square }\end{array}$ & $\begin{array}{c}\text { Std. Error of } \\
\text { the Estimate }\end{array}$ & $\begin{array}{c}\text { Durbin- } \\
\text { Watson }\end{array}$ \\
\hline 1 &, $695^{\mathrm{a}}$ &, 483 &, 455 & 1,405 & 1,976 \\
\hline
\end{tabular}

a. Predictors: (Constant), Kualitas Pelayanan, Lokasi, Harga

b. Dependent Variable: Minat Beli Konsumen

Output pada tabel di atas menunjukkan bahwa nilai Adjust R Square adalah 0,455, yang artinya adalah kemampuan variabel harga $\left(\mathrm{X}_{1}\right)$, lokasi $\left(\mathrm{X}_{2}\right)$, kualitas pelayanan $\left(\mathrm{X}_{3}\right)$ dalam mempengaruhi minat beli konsumen (Y) adalah sebesar 45,5\%, sedangkan 54,5\% dipengaruhi oleh variabel atau faktor lainnya yang tidak diteliti dalam penelitian ini.

\section{Hasil Uji t}

\begin{tabular}{lcr}
\hline Variabel & thitung & Signifikansi \\
\hline Harga & 1.991 & 0.051 \\
Lokasi & 2.178 & 0.034 \\
Kualitas Pelayanan & 3.291 & 0.002 \\
\hline
\end{tabular}

Berdasarkan hasil uji t bahwa nilai signifikansi thitung dari variabel harga $\left(\mathrm{X}_{1}\right)$ sebesar 1.991 dengan tingkat signifikansi 0,051, lokasi $\left(\mathrm{X}_{2}\right)$ sebesar 2.178 dengan tingkat signifikansi 0,034, dan kualitas pelayanan $\left(X_{3}\right)$ sebesar 3.291 dengan tingkat signifikansi 0,002 . Data tersebut menunjukkan bahwa secara parsial hanya variabel lokasi $\left(X_{2}\right)$ dan variabel kualitas pelayanan $\left(\mathrm{X}_{3}\right)$ yang memberikan pengaruh terhadap minat beli konsumen (Y), dikarenakan tingkat signifikansi dari thitung berada pada posisi dibawah 0,05 . Sedangkan harga $\left(\mathrm{X}_{1}\right)$ tidak berpengaruh terhadap minat beli konsumen dikarenakan tingkat signifikansi dari thitung berada pada posisi di atas 0,05 .

\section{Hasil Uji F}

ANOVA $^{\mathrm{a}}$

\begin{tabular}{|cc|c|c|c|c|c|}
\hline \multicolumn{1}{|c|}{ Model } & $\begin{array}{c}\text { Sum of } \\
\text { Squares }\end{array}$ & Df & Mean Square & F & Sig. \\
\hline \multirow{3}{*}{1} & Regression & 103,138 & 3 & 34,379 & 17,421 &, $000^{\mathrm{b}}$ \\
& Residual & 110,512 & 56 & 1,973 & & \\
& Total & 213,650 & 59 & & & \\
\hline
\end{tabular}

a. Dependent Variable: Minat Beli Konsumen 
b. Predictors: (Constant), Kualitas Pelayanan, Lokasi, Harga

Berdasarkan hasil uji $\mathrm{F}$ dapat disimpulkan bahwa tingkat signifikansi yang dihasilkan adalah sebesar 0.000 yang lebih kecil dari dari pada 0,05 . Sehingga hipotesis yang menyatakan bahwa ada pengaruh signifikan secara simultan dari variabel harga $\left(\mathrm{X}_{1}\right)$, lokasi $\left(\mathrm{X}_{2}\right)$ dan kualitas pelayanan $\left(\mathrm{X}_{3}\right)$ terhadap variabel minat beli konsumen $(\mathrm{Y})$ pada Pasar Usaha BUMDesa Pengalangan Menganti Gresik dapat diterima kebenarannya.

\section{Pembahasan}

Hasil analisis data menunjukkan bahwa terdapat hubungan kausal antara variabel Harga $\left(X_{1}\right)$, Lokasi $\left(X_{2}\right)$, Kualitas Pelayanan $\left(X_{3}\right)$ dengan variabel Minat Beli Konsumen (Y). Hal ini ditunjukkan dengan analisis regresi linier berganda dengan rumus $\mathrm{Y}=0,443$ $+0,318 \mathrm{X}_{1}+0,346 \mathrm{X}_{2}+0,342 \mathrm{X}_{3}$ data tersebut menunjukkan pengaruh harga $\left(\mathrm{X}_{1}\right)$ terhadap minat beli konsumen (Y) adalah positif sebesar 0,318 , serta pengaruh terhadap lokasi $\left(\mathrm{X}_{2}\right)$ terhadap minat beli $(\mathrm{Y})$ adalah positif sebesar 0,346 , serta pengaruh kualitas pelayanan $\left(\mathrm{X}_{3}\right)$ terhadap minat beli $(\mathrm{Y})$ adalah positif sebesar 0,342 . Data tersebut menunjukkan bahwa ketiga variabel bebas mempengaruhi secara signifikan terhadap variabel terikat yaitu minat beli konsumen (Y). Semakin terjangkau harga yang ditawarkan di Pasar Usaha BUMDesa Pengalangan, maka semakin tinggi minat beli konsumen. Hal ini didukung oleh penelitian yang dilakukan oleh Santoso dan Wirayanthy (2018); Kusuma (2015); dan Mustapa et al., (2018) yang menghasilkan bahwa harga terbukti berpengaruh terhadap minat beli konsumen. Selanjutnya lokasi Pasar Usaha BUMDesa Pengalangan memiliki pengaruh yang kuat dalam menentukan minat beli konsumen, hal ini sejalan dengan penelitian yang dilakukan Monica (2018) bahwa lokasi akan mempengaruhi minat konsumen untuk melakukan keputusan pembelian, selain itu kualitas pelayanan yang diberikan kepada konsumen juga mempengaruhi minat beli konsumen, kualitas pelayanan yang diberikan oleh pedagang dan konsumen dapat merasakan kualitas pelayanan yang diberikan sehingga konsumen dapat merasakan kepuasan dari pelayanan pedagang yang diberikan di Pasar Usaha BUMDesa Pengalangan, hal ini juga di dukung oleh penelitian yang dilakukan Aptaguna dan Pitaloka (2016); Bahar \& Sjaharuddin (2015); dan Faradiba dan Astuti (2013) bahwa kualitas pelayanan juga mempengaruhi minat beli konsumen.

Hasil analisis koefisien determinasi berganda menunjukkan bahwa Adjust R square adalah 0,455 , yang artinya adalah kemampuan variabel harga $\left(\mathrm{X}_{1}\right)$, lokasi $\left(\mathrm{X}_{2}\right)$, kualitas pelayanan $\left(\mathrm{X}_{3}\right)$ dalam mempengaruhi minat beli konsumen $(\mathrm{Y})$ adalah sebesar $45,5 \%$, sedangkan 54,5\% dipengaruhi oleh variabel atau faktor lainnya yang tidak diteliti dalam penelitian ini. Hal ini sesuai dengan penelitian yang dilakukan oleh Santoso dan Wirayanthy (2018)yang menunjukkan bahwa selain harga, citra merek juga berpengaruh terhadap minat beli konsumen.

Hasil uji t menunjukkan bahwa signifikansi $t_{\text {hitung }}$ dari variabel harga $\left(\mathrm{X}_{1}\right)$ sebesar 1,991 dengan tingkat signifikansi 0,051, lokasi $\left(\mathrm{X}_{2}\right)$ sebesar 2.178 dengan tingkat 
signifikansi 0,034, dan kualitas pelayanan $\left(\mathrm{X}_{3}\right)$ sebesar 3,291 dengan tingkat signifikansi 0,002. Data tersebut menunjukkan bahwa secara parsial hanya variabel lokasi $\left(\mathrm{X}_{2}\right)$ dan variabel kualitas pelayanan $\left(\mathrm{X}_{3}\right)$ yang memberikan pengaruh terhadap minat beli konsumen (Y), dikarenakan tingkat signifikansi dari $\mathrm{T}_{\text {hitung }}$ berada pada posisi dibawah 0,05 sedangkann harga $\left(\mathrm{X}_{1}\right)$ tidak berpengaruh terhadap minat beli konsumen dikarenakan tingkat signifikansi dari $t_{\text {hitung }}$ berada pada posisi di atas 0,05 . Penelitian ini tidak sejalan dengan penelitian yang dilakukan oleh Latief (2018) yang menunjukkan bahwa harga secara parsial berpengaruh terhadap minat beli konsumen.

Hasil uji $\mathrm{F}$ atau uji simultan menunjukkan bahwa tingkat signifikansi yang dihasilkan adalah sebesar 0.000 yang lebih kecil dari dari pada 0,05. Sehingga hipotesis yang menyatakan bahwa ada pengaruh signifikan secara simultan dari variabel harga $\left(\mathrm{X}_{1}\right)$, lokasi $\left(\mathrm{X}_{2}\right)$ dan kualitas pelayanan $\left(\mathrm{X}_{3}\right)$ terhadap variabel minat beli konsumen $(\mathrm{Y})$ pada Pasar Usaha BUMDesa Pengalangan Menganti Gresik dapat diterima kebenarannya. Penelitian ini sejalan dengan penelitian yang dilakukan oleh Monica (2018) yang menunjukkan bahwa Harga dan lokasi berpengaruh positif dan signifikan terhadap minat beli serta penelitian yang dilakukan Aptaguna dan Pitaloka (2016) yang menunjukkan kualitas pelayanan berpengaruh positif dan signifikan terhadap minat beli konsumen.

\section{KESIMPULAN DAN SARAN}

Dengan memperhatikan hasil penelitian pada bab sebelumnya, maka peneliti memperoleh kesimpulan sebagai berikut :

1. Harga, lokasi, dan kualitas pelayanan berada pada posisi skor baik sedangkan minat beli konsumen berada di posisi skor sangat baik pada Pasar Usaha BUMDesa Pengalangan Menganti Gresik.

2. Secara parsial Lokasi dan kualitas pelayanan berpengaruh positif signifikan terhadap minat beli konsumen, sedangkan harga tidak berpengaruh terhadap minat beli konsumen pada Pasar Usaha BUMDesa Pengalangan Menganti Gresik.

3. Secara simultan harga, lokasi dan kualitas pelayanan berpengaruh positif signifikan terhadap minat beli konsumen pada Pasar Usaha BUMDesa Pengalangan Menganti Gresik.

Dalam penelitian ini, peneliti memiliki beberapa saran sebagai berikut:

1. Bagi Pasar Usaha BUMDesa Pengalangan Menganti Gresik disarankan untuk memonitor harga yang ditetapkan para pedagang, agar harga selalu stabil, untuk lokasi agar selalu dijaga dan ditingkatkan supaya menjadi lebik baik, untuk kualitas pelayanan selalu dijaga dan terus ditingkatkan agar semakin baik.

2. Disarankan untuk penelitian selanjutnya untuk melakukan pengembangan penelitian dengan mencari faktor-faktor lain yang dapat berpengaruh terhadap minat beli konsumen dikarenakan dalam penelitian ini variabel harga, lokasi dan kualitas pelayanan memberikan pengaruh yang kecil terhadap minat beli konsumen. 


\section{DAFTAR PUSTAKA}

Adiba. (2016). Pengaruh Suasana Toko dan Lokasi Terhadap Minat Beli Konsumen Pada Toko Aurora Shop Samarinda. eJournal Administrasi Bisnis, 4(3), 670-682

Ali, H., dan Novansa, H. (2017). Purchase Decision Model : Abalysis of Brand Image, Brand Awareness and Price (Case study SMECO Indonesia SME Product). Journal of Humanities and Social Sciences, Vol 2. No 8, 621-632.

Aptaguna dan Pitaloka. (2016). Pengaruh Kualitas Layanan Dan Harga Terhadap Minat Beli Jasa Go-Jek. Jurnal Program Studi Manajemen Universitas Pembangunan Jaya,3(2), 18-31

Arikunto, S. (2010). Prosedur Penelitian (Suatu Pendekatan Praktik). Jakarta: Rineka Cipta

Bahar, A., \& Sjaharuddin, H. (2015). Pengaruh Kualitas Produk Dan Kualitas Pelayanan Terhadap Kepuasan Konsumen Dan Minat Beli Ulang. Jurnal Organisasi Dan Manajemen, 3(2), 14-34

Digdoyo, E. (2015). Ilmu Sosial dan Budaya Dasar. Bogor: Ghalia Indonesia.

Faradiba., dan Astuti, S. R. T. (2013). Analisis Pengaruh Kualitas Produk, Harga, Lokasi Dan Kualitas Pelayanan Terhadap Minat Beli Ulang Konsumen (Studi pada Warung Makan "Bebek Gendut" Semarang). Diponegoro Journal Of Management, 2(3), 1-11

Kotler, P., dan Keller, K. L. (2016). Manajemen Pemasaran edisi 12 Jilid 1 \& 2. Jakarta: PT. Indeks.

Kusuma, A. F. (2015). Pengaruh Harga, kualitas, Dan Resiko Yang Dipersepsikan Terhadap Minat Pembelian Produk Merek Alfamart Di Surabaya. Working Paper: STIE Perbanas Surabaya.

Latief, A. (2018). Analisis Pengaruh Produk, Harga, Lokasi dan Promosi terhadap Minat Beli Konsumen pada Warung Wedang Jahe (Studi Kasus Warung Sido Mampir di Kota Langsa). Jurnal Manajemen dan Keuangan. Vol.7, No.1, 1-15.

Lupiyoadi. (2001). Manajemen Pemasaran Jasa Teori dan Praktek. Jakarta: Salemba Empat.

Monica. (2018). Pengaruh Harga, Lokasi, Kualitas Bangunan Dan Promosi Terhadap Minat Beli Perumahan Taman Safira Bondowoso. International Journal of Social Science and Business, Vol. 2, No. 3.

Mustapa, A., Patricia, D. P., \& Leonardo, B. H. (2018). Pengaruh kualitas produk, harga produk, dan keragamaan produk sparepart toyota terhadap minat beli ulang konsumen dengan kepuasaan pelanggan sebagai variabel. Journal of Management Universitas pandanaran 4 (4): 1-17.

Satria, A. (2017). Pengaruh Harga, Promosi, dan Kualitas Produk Terhadap Minat Beli Konsumen Pada Perusahaan A-36. Jurnal Manajemen dan Start-Up Bisnis, 2(2), 1-15 
Sugiyono. (2019). Metode Penelitian Kuantitatif, Kualitatif $R \&$ D. Bandung: Alfabeta.

Tjiptono, F. (2016). Service, Quality \& satisfaction. Yogyakarta: Andi

Umar, H. (2003). Studi Kelayakan Bisnis. Jakarta: Gramedia Pustaka Utama.

Utami, R.P., dan Saputra, H. (2017). Pengaruh Harga dan Kualitas Produk Terhadap Minat Beli Sayuran Organik Di Pasar Sambas Medan. Jurnal Niagawan, 6(2), 4453

Wirayanthy, N., dan Santoso, S. (2019). Pengaruh Harga Citra Merek Dan Kualitas Terhadap Minat Beli Produk Private Label. JMD: Jurnal Riset Manajemen \& Bisnis Dewantara, 1(2), 29-42. 